${ }^{\circ}$ Entomologica Fennica. 19 June 1996

\title{
Licinus depressus (Coleoptera, Carabidae) - a new species for Tavastia Australis - Finland
}

\author{
Heidi Kinnunen
}

\begin{abstract}
Kinnunen, H. 1996: Licinus depressus (Coleoptera, Carabidae) - a new species for Tavastia Australis - Finland. - Entomol. Fennica 7: 5-6.
\end{abstract}

Heidi Kinnunen, Department of Ecology and Systematics, Division of Population Biology, P.O. Box 17, FIN-00014 University of Helsinki, Finland

Received 14 November 1995, accepted 15 December 1995

In summer 1993 I caught one specimen of Licinus depressus (Paykull) in a pitfall trap in Asikkala in a large patch of farmland (6788:415). Fifteen traps were placed in a grid of $3 \times 5$, with a distance of about three metres from each other, over the period 16 August-30 August in a field temporarily taken out of use. Other species caught from the same place were Pterostichus niger (Illiger), Badister lacertosus (Sturm), and Trechus secalis (Paykull). Exactly a year after the first find, two males and one female of $L$. depressus were caught in pitfall traps in the same place. This time the grid was larger, i.e. $4 \times 5$ traps. Other carabid species caught in the traps were Amara aulica (Panzer), A. bifrons (Gyllenhal), Harpalus rufipes (Degeer), H. rufibarbis (Fabricius), Calathus melanocephalus (Linnaeus) and Trechus secalis (Paykull); these species were abundant in the area.

According to Brandmayr \& Brandmayr (1986), at least the $\mathrm{S}$ European Licinus cassideus (Dejean), L. hoffmannseggi (Panzer) and L. italicus (Puel), are highly oligophagous predators of terrestrial gastropods. L. depressus, the only representative of the genus in Fennoscandia, is also a specialized snaileater (Lindroth 1986). The following snail species were found in my pitfall traps: Nesovitrea hammonis (Ström), N. petronella (Pfeiffer), Cochlicopa lubrica (Müller), C. lubricella (Porro) and Vallonia costata (Müller). These species are rather small, being only 2-6 mm long, and seem to be the main food source for $L$. depressus. Thus, it is possible that the feeding habits of the carabid more or less restrict the habitats of the species to areas with dry, sandy or gravelly soil, often mixed with clay or chalk, i.e. areas where small snails are common (Lindroth 1986).

In Denmark, $L$. depressus is known only from the Islands of Lolland, Falster, Møn, and Bornholm, but no records are known after 1955 (Bangsholt 1983). In Sweden the species is rare and scattered in the south, and has not been found further north than Västmanland; in Skania and on the islands of Öland and Gotland, as well as in the Mälaren valley, the species is somewhat more common. In Estonia $L$. depressus is restricted to some locations on the Island of Saaremaa and along the northern coast of the country (Haberman 1968).

In Finland the species is very rare, with some old records from the Åland Islands and Kaarina, Kuusisto and later finds from Turku in 1966, and Pargas in 1979 (Lindroth 1949, 1986, Rassi 1993.). The species is not considered endangered in Finland or Sweden (Rassi \& Väisänen 1987, Ehnström et al. 1993).

My specimens appear to be the northernmost ever found. Since the wings of the species are rudimentary, dispersal from areas where the species is more common is obviously slow (cf. Lindroth 1949,1986 ). The discovery in the province of $T a$ extends the distribution of the species more than $100 \mathrm{~km}$ north of the previously known range. The finds also indicate that there is a viable population in Asikkala. From the data available, it is impossi- 
ble to say whether this is an isolated single population on the Finnish mainland. Chalcareous soils are rare in Finland and if the species is restricted to such places, its distribution must be rather patchy.

Acknowledgements. My sincere thanks are due to Hans Silfverberg and Jaakko Kullberg who kindly checked my determination of $L$. depressus. I also wish to thank Ilmari Valovirta for identifying the molluscs. Comments on the manuscript by Juha Tiainen are appreciated.

\section{References}

Bangsholt, F. 1983: Sandspringernes og løbebillemes udbredelse of forekomst i Danmark ca. 1830-1981: (Coleoptera: Cicindelidae and Carabidae) - Scandinavian Science Press, Kobenhavn, 271 pp.

Brandmayr, P. \& Brandmayr, T. Z. 1986: Food and behavior of some Licinus species (Coleoptera, Carabidae, Licini). -Monit. Zool. Ital. 20:171-181.

Ehnström, B., Gärdenfors, U. \& Lindelöw, A. 1993: Rödlistade evertebrater i Sverige 1993 - Databanken för hotade arter. Sveriges lantbruksuniversitet. Reklam \& Katalogtryck, Uppsala, 69 pp.

Haberman, H. 1968: Eesti jooksiklased (Coleoptera, Carabidae) —Eesti NSV Teaduste Akadeemia Zoologia ja Botaanika Instituut. Kirjastus "Valgus", Tallinn, 597 pp.

Lindroth, C. H. 1949: Die Fennoskandischen Carabidae. III. Allgemeiner Teil - Göteborgs Kgl. Vet. Vitterh. Samh. Handl. (B) 4:1-911.

- 1986: The Carabidae (Coleoptera) of Fennoscandia and Denmark. - Fauna Entomol. Scand. 15:233-497.

Rassi, P. 1993: Suomen kovakuoriaisten frekvenssipisteet 1.1.1960-1.1.1990. - WWF. Helsinki, 136 pp.

Rassi P. \& Väisänen, R. (eds.) 1987: Threatened animals and plants in Finland. English summary of the report of the committee for the conservation of threatened animals and plants. - Committee report 43, Ministery of the Environment, Helsinki, $82 \mathrm{pp}$. 